\title{
Intercropping of Sweet Basil (Ocimum Basilicum L.) with Maize (Zea Mays L.) as Supplementary Income Generation at Wondo Genet Agricultural Research Center, South Ethiopia
}

\author{
Nebret Tadesse $^{1 *}$, Midhekisa Chala $^{2}$, Basazinew Degu ${ }^{1}$ \\ ${ }^{1}$ Wondo Genet Agricultural Research Center, EIAR, P.O. Box: 198, Shashemene, Ethiopia. \\ ${ }^{2}$ Ambo Agricultural Research Center, EIAR, P.O. Box: 37 Ambo, Ethiopia.
}

*Corresponding Author: Nebret Tadesse, Wondo Genet Agricultural Research Center, EIAR, P.O. Box: 198, Shashemene, Ethiopia.

\begin{abstract}
Field experiments were conducted at wondo genet research center in 2017 and 2018 cropping seasons. The aim of the study was to determine the optimum population density of sweet basil intercropping ratio into a maize-based cropping system. The experiment was laid out in randomized complete design using five intercropping ratios $=T 1=$ sole basil, $T 2=$ maize sole, $T 3=100 \%$ maize $+100 \%$ Sweet Basil, $T 4=100 \%$ Maize+75\% Sweet Basil, T5=100\% Maize+50\% Sweet Basil, T6=100\% Maize $+25 \%$ Sweet Basil. Combined mean grain yield of maize was not significantly affected by treatment of intercropping ratio of basil, whereas mean herbage yield of basil was significantly affected by the intercropping ratio of basil proportion in maize. The combined mean yield advantage in terms of total LER indices was greatest in the cases of 100\% sweet basil into 100\% maize intercropping (1.66) which might be attributed to more efficient total resource exploitation and greater overall production. Intercropping basil population in $100 \%$ and $75 \%$ in to $100 \%$ maize gave higher mean grain yield of maize, basil herbage and economically profitable as compared to sole maize and sole basil cropping therefore we recommend intercropping $75 \%$, up to $100 \%$ sweet basil population in maize is would be profitable for small scale farmers who practice monocropping around wondo genet and similar agro-ecology.
\end{abstract}

Keywords: Intercropping ratio, Sweet Basil, Maize, Land Equivalent Ratio and Economic Advantage

\section{INTRODUCTION}

Intercropping as a method of sustainable agriculture is the growing of two or more crops during the same season on the same area so as to utilize common limiting resources better than the species grown separately, and hence it is as an efficient resource use method (Ghosh et al., 2006). Now a day this method has become one of the popular methods in the agricultural system due to the more efficient use of resources and its role in the reduction in weeds interference and other pests (Chen et al., 2012; Lithourgidis et al., 2011). It should be kept in mind that intercropping has a long history of food production in the world.

According to Seran and Brintha, (2010) the intercropping system gave higher cash return to smallholder farmers than growing as the mono-crops. Intercropping maize with cowpea has been reported to increase light interception in the intercrops, reduce water evaporation, and improve conservation of the soil moisture compared with maize grown alone (Ghanbari et al, 2010).

Medicinal plants are considered as a source of health products, essential oils and other natural aroma chemicals in the national and international markets (Sujatha et al., 2011). In addition, many studies have emphasized the use of medicinal plants in intercropping systems, such as cassava/okra, Okra with chili pepper, saffron, and chamomile, were also reported by Muoneke and Mbah, (2007), Uddin and Odebiyi, (2011).

In addition, to conserve the biodiversity, presence of medicinal plants in intercropping will also enhance yield quantity. For example, intercropping peppermint (Mentha piperita) plants with soybean produced a significantly higher amount of essential oil when compared to monoculture plants and the oil yield increased by 50\% (Maffei and Mucciarelli, 2003). 
In many studies, one of the most common reasons for the adoption of intercropping is yield beneficial which is justified by the greater resource exploitation by intercrops than monoculture (Poggio, 2005). The more efficient exploitation of resources in intercropping happens because the component crops use the resources either at different times or obtain resources from different parts of soil or aerial environment (Echarte et al., 2011). Regarding yield advantage, in a field study, Esmaeili et al. (2011) reported that the total seed yield of barley (Hordeum vulgare) and annual medic (Medicago scutellata) was improved in some of the intercropping ratios when compared to the monoculture of either crop.

Another advantage of intercropping systems is weed suppression (Banik et al., 2006). The reduction of weed growth by crop interference is a viable alternative to reduce the reliance on herbicide application in weed management (Poggio, 2005). Even though maize is a major food crop produced in south Ethiopia, there is a little bit information on intercropping with aromatic plants such as sweet basil. Basil (Ocimum basilicum L.) is an erect herbaceous annual aromatic, spice and medicinal plant that belongs to the Lamiaceae family (Helen, 1980). In Ethiopia, sweet basil is locally known as "Besso bila" in Amharic and different Ethiopian ethnic group has a different name for sweet basil, (Gebrehiwot, et al., 2015). Common basil or sweet basil (O. basilicum L.) is most widely used due to its high economic value, popularity, and demands among these economically important species of basil (Simon et al., 1999). Ethiopian farmers conventionally cultivate and use this crop for house consumption and provide for the local market and some investors started exportation of sweet basil to different countries (Yimer, 2010). Some finding indicated that identifying compatibility and profitability of intercropping aromatic and medicinal plant with major growing crops in Ethiopia. As explained by Lulie (2014), intercropping spearmint with maize at a $42 \mathrm{~cm}$ inter-row spacing of spearmint followed by $36 \mathrm{~cm}$ inter-row spacing is biologically efficient, economically feasible, more profitable and provide opportunities for the producers than planting alone. Therefore, the main objectives of this study were to assess the influence of intercropping sweet basil with maize on yield and yield component of maize and basil yield. To diversify maize-sweet basil based farming practices by the inclusion of sweet basil for additional cash generation.

\section{MATERIAL AND MethodS}

The research was conducted at Wondo Genet Agricultural Research Center's fields, in Southern Ethiopia during 2017 and 2018 growing seasons. Wondo Genet is located $270 \mathrm{~km}$ South of Addis Abeba and $14 \mathrm{~km}$ southeast of Shashemene. The geographical coordination of the area is $7^{0} 19^{\prime} \mathrm{N}$ latitude and $38^{\circ} 38^{\prime} \mathrm{E}$ longitudes with an altitude of 1780 meters above sea level (masl). The site receives a mean annual rainfall of $1128 \mathrm{~mm}$ with minimum and maximum temperature of $11^{\circ} \mathrm{C}$ and $26^{\circ} \mathrm{C}$, respectively

The experiment was laid out in a randomized complete block design with three repeats. The treatments consisted with six additive series intercropping combinations viz: $\mathrm{T} 1=$ sole Basil $(60 \mathrm{~cm}$ inter-row with $40 \mathrm{~cm}$ intra-row spacing ), T2=Sole maize $(80 \mathrm{~cm} \times 30 \mathrm{~cm}), \mathrm{T} 3=100 \%$ maize $+100 \%$ Sweet Basil (60 $\mathrm{cm}$ inter-row x 40cm intra-row), T4=100\% Maize $+75 \%$ Sweet Basil (Jumping two rows of maize + one row of sweet Basil with 50cm intra-row), T5=100\% Maize $+50 \%$ Sweet Basil (jumping two row of maize + one row of Sweet Basil with 40cm intra-row), T6 $=100 \%$ Maize $+25 \%$ Sweet Basil ( jumping two row of maize + one row of sweet Basil with $60 \mathrm{~cm}$ intra row spacing. Maize variety BH546 was used and spaced at a distance $30 \mathrm{~cm} \times 80 \mathrm{~cm}$ with $41663 \mathrm{ha}^{-1}$ plant population and the companion crop was Sweet Basil. Maize seeds were sown at the rate of two seeds per hill and simultaneously uniform sweet basil seedlings were transplanted at the height of around $15 \mathrm{~cm}$ or two months after sowing according to the treatments. Maize was thinned to one plant per hill after three weeks. Gross plot size of the experiment was $16 \mathrm{~m}^{2}(4 \mathrm{~m} \times 4 \mathrm{~m})$ and the distance between the plots and blocks were 1 and 1.5 $\mathrm{m}$ apart respectively. Each plot consisted of five rows of maize. The net central unit areas $(2.4 \mathrm{~m} \mathrm{x}$ $3.4 \mathrm{~m}=8.16 \mathrm{~m} 2$ ) of each plot excluding the borders were used for data collection. Recommended hand weeding and harvesting practices were followed, and fertilizers were applied at rates of $50 \mathrm{~kg}$ urea and $46 \mathrm{~kg} \mathrm{Pha}^{-1}$.

\subsection{Data Collection and Measurements}

Data for maize on plant height, cobs per plant, cob length, and data for sweet basil on plant height were determined from 10 randomly sampled plants per plot during physiological maturity. The maize grain yield, leaf and inflorescence weight per plant (gm), dry herbal yield $\mathrm{kg} \mathrm{ha}^{-1}$, and Oil yield $\mathrm{kg} \mathrm{ha}^{-1}$ 
of each crop of the component crop in the intercrop was determined from the harvestable plots and converted to $\mathrm{kg} \mathrm{ha}^{-1}$. Sweet basil leaf and inflorescence oil extraction were done using the hydrodistillation method in a Clevenger type apparatus. Analysis of variance was used to test the significance of treatment effects using the computer program SAS 9.1.3. Least Significant Difference (LSD) test was used to compare treatment means.

Land equivalent ratio (LER) was determined using the formula defined by Willey (1991)

$\mathrm{LER}=\mathrm{La}+\mathrm{Lb}=\mathrm{Yab} / \mathrm{Yaa}+\mathrm{Y}$ ba/Ybb

Where $\mathrm{Lm}$ and $\mathrm{Lb}$ are the LERs for the individual crops of the system

Ymb = Intercrop yield of crop 'Maize'

$\mathrm{Ybm}=$ Intercrop yield of crop 'sweet Basil'

Ymm = Pure stand crop yield of 'Maize'

$\mathrm{Ybb}=$ Pure stand crop yield of 'sweet basil'

Economic benefits of maize-basil intercropping were determined by calculating monetary advantage index (MAI) using formula established by Willey (1979). Prevailing local market prices of maize and basil were taken for economic analysis and the prices of maize and basil were 5.5 and 30 ETB/Ethiopian Birr), respectively, during the experiment.

MAI $=($ Value of combined intercrops $) \times($ LER-1)/LER

Where MAI $=$ Monetary advantage index

LER $=$ Land equivalent ratio

\section{RESULTS AND DiSCUSSION}

\subsection{Maize Components}

Among all measured parameters of maize for two years only in the first year; above ground biomass had a significant difference. The highest above ground biomass $\left(18706 \mathrm{~kg} \mathrm{ha}^{-1}\right)$ was recorded from sole maize followed by $25 \%$ of sweet basil intercropping in maize $\left(13483 \mathrm{~kg} \mathrm{ha}^{-1}\right)$ and the lowest $\left(10502 \mathrm{kgha}^{-1}\right)$ was obtained from $100 \%$ of sweet bail with $100 \%$ maize it indicated that intercropping highest present of sweet basil in maize affect the biomass of maize. However, the second year and the combined mean were not significantly affected above ground biomass of maize.

Similarly, Ghanizadeh et al. (2014) reported that the total yield of sole maize was more than their intercrops in maize: sweet basil: borage intercropping.

Table1. Influence of Maize- Sweet Basil intercropping on yield and yield components of maize for two consecutive years

\begin{tabular}{|c|c|c|c|c|c|c|}
\hline Treatments & \multicolumn{3}{|c|}{ Plant height $(\mathrm{m})$} & \multicolumn{3}{c|}{ Number of Ear per plant } \\
\hline Years & 2017 & 2018 & Combined mean & 2017 & 2018 & Combined mean \\
\hline Sole Maize & 2.56 & 2.37 & 2.57 & 1.3 & 1.3 & 1.4 \\
\hline 100\% Maize+100\% Sweet Basil & 2.71 & 2.33 & 2.36 & 1.7 & 1.5 & 1.3 \\
\hline 100\% Maize+ 75\% Sweet Basil & 2.76 & 2.23 & 2.58 & 1.3 & 1.2 & 1.4 \\
\hline 100\% Maize+50\% Sweet Basil & 2.54 & 2.55 & 2.39 & 1.2 & 1.3 & 1.0 \\
\hline 100\% Maize+25\% Sweet Basil & 2.56 & 2.16 & 2.62 & 1.4 & 1.3 & 1.6 \\
\hline LSD $_{0.05}$ & $\mathrm{~ns}$ & $\mathrm{~ns}$ & $\mathrm{~ns}$ & $\mathrm{~ns}$ & $\mathrm{~ns}$ & $\mathrm{~ns}$ \\
\hline CV\% & 7.6 & 4.7 & 5.1 & 18.3 & 24.2 & 23 \\
\hline
\end{tabular}

Also, Girma (2015) stated that the highest biological yield obtained from monoculture than intercropped. The higher yield of monoculture compared to intercrop may be due to minimal disruption of the plant's habitat (Banik et al., 2006).

Table2. Influence of Maize- Sweet Basil intercropping on yield and yield components of maize for two consecutive years

\begin{tabular}{|c|c|c|c|c|c|c|}
\hline Treatments & \multicolumn{3}{|c|}{ Ear length $(\mathrm{cm})$} & \multicolumn{3}{c|}{ Grain yield $\left(\mathrm{kg} \mathrm{ha}^{-1}\right)$} \\
\hline Years & 2017 & 2018 & Combined mean & 2017 & 2018 & Combined mean \\
\hline Sole Maize & 17.7 & 20.1 & 19.52 & 6262 & 5276.9 & 5769.4 \\
\hline $100 \%$ Maize+100\% Basil & 17.5 & 19.9 & 18.4 & 6079.6 & 4262.2 & 5751.8 \\
\hline $100 \%$ Maize+ 75\% Basil & 18.7 & 19.3 & 18.9 & 6441.2 & 5163.4 & 5609.3 \\
\hline
\end{tabular}


Intercropping of Sweet Basil (Ocimum Basilicum L.) with Maize (Zea Mays L.) as Supplementary Income Generation at Wondo Genet Agricultural Research Center, South Ethiopia

\begin{tabular}{|c|c|c|c|c|c|c|}
\hline $100 \%$ Maize+50\% Basil & 18.6 & 19.6 & 19.2 & 5811.2 & 4777.4 & 5487.3 \\
\hline $100 \%$ Maize+25\% Basil & 18.6 & 19.6 & 19.2 & 6424.3 & 5424.1 & 5343.3 \\
\hline LSD $_{0.05}$ & $\mathrm{~ns}$ & $\mathrm{~ns}$ & $\mathrm{Ns}$ & $\mathrm{ns}$ & $\mathrm{ns}$ & $\mathrm{ns}$ \\
\hline CV\% & 2.9 & 3.18 & 2.25 & 12.6 & 19.24 & 14.0 \\
\hline
\end{tabular}

The other parameters; - plant height $(\mathrm{cm})$, number of ear per plant, ear length, grain yield, and Harvest index were not showed significant differences among the intercropped ratio of basil in $100 \%$ of maize or in another word those parameters don't influence by the intercropping population density of sweet basil; this could be due to the reason that intercropping sweet basil in maize at an early stage or immediately after maize emerged doesn't affect maize growth parameters and grain yield; on the other hand before the canopy of maize formed and competition occurred sweet basil harvesting time reached within two and half month (Table 1, 2, \& 3).

Table3. Influence of Maize-Basil intercropping on yield and yield components of maize for two consecutive years

\begin{tabular}{|c|c|c|c|c|c|c|}
\hline Treatments & \multicolumn{2}{|c|}{ Aboveground biomass $\left(\mathrm{kg} \mathrm{ha}^{-1}\right)$} & \multicolumn{3}{c|}{ Harvest index } \\
\hline Years & 2017 & 2018 & Combined mean & 2017 & 2018 & Combined mean \\
\hline Sole Maize & $18706 \mathrm{a}$ & 10045 & 12969.9 & 0.34 & 0.54 & 0.45 \\
\hline $100 \%$ Maize+100\% Basil & $10502 \mathrm{~b}$ & 9868 & 11750.0 & 0.63 & 0.54 & 0.47 \\
\hline $100 \%$ Maize+ 75\% Basil & $10577 \mathrm{~b}$ & 9742 & 12311.4 & 0.65 & 0.52 & 0.46 \\
\hline $100 \%$ Maize+50\% Basil & $12967 \mathrm{~b}$ & 9693 & 11940.4 & 0.45 & 0.47 & 0.46 \\
\hline $100 \%$ Maize+25\% Basil & $13483 \mathrm{ab}$ & 8044 & 11520.2 & 0.45 & 0.53 & 0.50 \\
\hline LSD $_{0.05}$ & $5245.8^{*}$ & $\mathrm{~ns}$ & $\mathrm{~ns}$ & $\mathrm{~ns}$ & $\mathrm{~ns}$ & $\mathrm{~ns}$ \\
\hline CV\% & 21.0 & 13.1 & 7.9 & 27.1 & 14.9 & 8.9 \\
\hline
\end{tabular}

\subsection{Basil Component}

In each year and the combined mean plant height was significantly $(\mathrm{P}<0.05)$ affected by the intercropping ratio of sweet basil. Sweet bail planted at the ratio of $100 \%$ basil with $100 \%$ maize gave higher mean plant height $(50.5 \mathrm{~cm})$, followed by decreasing consecutively with a decreased ratio of basil (Table 4). Such an increase in plant height with increased plant density may be explained by increased activity of stem growth hormone for plant sunlight competition. This finding was consistent with the data reported by Girma (2015) who observed that taller basil plants were achieved from the high intercropping population density of basil-maize intercropping. Significantly higher combined mean fresh leaf yield per plant $\left(40.1 \mathrm{kgp}^{-1}\right)$ was obtained from sole basil. Even though statistically were not significant difference observed between the intercropping ratio of basil in maize from $25 \%$ up to $100 \%$; here are increments of value when the percent of basil decreased in maize (Table 4). This might be due to the shade effect of maize and competition. Dry herbage yield and oil yield were significantly influenced by the intercropping ratio of basil in maize. The Combined mean higher dry herbage yield $\left(1560 \mathrm{~kg} \mathrm{ha}^{-1}\right)$ and oil yield $\left(7.95 \mathrm{~kg} \mathrm{ha}^{-1}\right)$ were obtained from the sole basil followed by the intercropping ratio of $100 \%$ basil in $100 \%$ maize for both and the lowest combined mean dry herbage $\left(485 \mathrm{~kg} \mathrm{ha}^{-1}\right)$ and oil yield $\left(3.3 \mathrm{~kg} \mathrm{ha}^{-1}\right)$ were obtained from the intercropping ratio of $25 \%$ basil in maize treatment.

Table4. Influence of Maize- Basil intercropping on yield and yield components of Basil for two consecutive years

\begin{tabular}{|c|c|c|c|c|c|c|}
\hline & \multicolumn{3}{|c|}{ Plant height $(\mathrm{cm})$} & \multicolumn{3}{c|}{ Leaf weight per plant (gm) } \\
\hline Treatments & 2017 & 2018 & Combined Mean & 2017 & 2018 & Combined Mean \\
\hline Sole basil & $43.2 \mathrm{c}$ & $41.3 \mathrm{ab}$ & $42.2 \mathrm{~cd}$ & $44.2 \mathrm{a}$ & 36.1 & $40.1 \mathrm{a}$ \\
\hline $100 \%$ Maize+100\%Basil & $53.9 \mathrm{a}$ & $47.06 \mathrm{a}$ & $50.5 \mathrm{a}$ & $14.1 \mathrm{~b}$ & 27.3 & $20.7 \mathrm{~b}$ \\
\hline $100 \%$ Maize+75\%Basil & $51.9 \mathrm{a}$ & $40.5 \mathrm{~b}$ & $46.2 \mathrm{~b}$ & $14.8 \mathrm{~b}$ & 25.4 & $20.7 \mathrm{~b}$ \\
\hline $100 \%$ Maize+50\%Basil & $55 \mathrm{a}$ & $35.6 \mathrm{~b}$ & $45.3 \mathrm{bc}$ & $18.7 \mathrm{~b}$ & 27.8 & $23.24 \mathrm{~b}$ \\
\hline $100 \%$ Maize+25\%Basil & $47.5 \mathrm{~b}$ & $36.2 \mathrm{~b}$ & $41.8 \mathrm{~d}$ & $17.2 \mathrm{~b}$ & 40.1 & $28.6 \mathrm{~b}$ \\
\hline LSD $_{0.05}$ & $4.2^{*}$ & $6.1^{*}$ & $3.4^{*}$ & $9.2^{*}$ & $\mathrm{~ns}$ & $11.4^{*}$ \\
\hline CV\% & 3.5 & 5.9 & 3.03 & 22.3 & 29 & 22.6 \\
\hline
\end{tabular}

This higher dry herbage yield and oil yield insole and in $100 \%$ basil in $100 \%$ maize treatment attributed to competition free and the accommodation of the high number of basil per unit area contribute to producing high biomass of herbage yield (Table 5). This finding was consistent with the result of Girma (2015) who reported higher dry herbage yield at maize: sweet basil (1:1) intercropping. 
Intercropping of Sweet Basil (Ocimum Basilicum L.) with Maize (Zea Mays L.) as Supplementary Income Generation at Wondo Genet Agricultural Research Center, South Ethiopia

Table5. Influence of Maize-Basil intercropping on yield and yield components of Basil for two consecutive years

\begin{tabular}{|c|c|c|c|c|c|c|}
\hline & \multicolumn{3}{|c|}{ Dry herbage weight $\left(\mathrm{kg} \mathrm{ha}^{-1}\right)$} & \multicolumn{3}{c|}{ Oil yield $\left(\mathrm{kgha}^{-1}\right)$} \\
\hline Treatments & 2017 & 2018 & Combined Mean & 2017 & 2018 & Combined Mean \\
\hline Sole basil & $1926.6 \mathrm{a}$ & $1501 \mathrm{a}$ & $1560 \mathrm{a}$ & $7.8 \mathrm{aa}$ & 8.05 & $7.95 \mathrm{a}$ \\
\hline $100 \%$ Maize+100\%Basil & $544.9 \mathrm{~b}$ & $1331 \mathrm{ab}$ & $938.1 \mathrm{~b}$ & $6.1 \mathrm{a}$ & 4.8 & $4.62 \mathrm{ab}$ \\
\hline $100 \%$ Maize+75\%Basil & $532.3 \mathrm{~b}$ & $793.5 \mathrm{~cd}$ & $662.9 \mathrm{bc}$ & $3.5 \mathrm{~b}$ & $6 . .0$ & $4.5 \mathrm{ab}$ \\
\hline $100 \%$ Maize+50\%Basil & $423.4 \mathrm{~b}$ & $956.8 \mathrm{bc}$ & $644.6 \mathrm{bc}$ & $2.5 \mathrm{bb}$ & 66.6 & $4.2 \mathrm{ab}$ \\
\hline $100 \%$ Maize+25\%Basil & $332.4 \mathrm{~b}$ & $386 \mathrm{~d}$ & $485 \mathrm{c}$ & $6.1 \mathrm{a}$ & 2.3 & $3.3 \mathrm{~b}$ \\
\hline LSD $_{0.05}$ & $407.04^{*}$ & $494.1 *$ & $348.2^{* * *}$ & $2.6^{*}$ & Ns & $4.2^{*}$ \\
\hline CV\% $^{10} \%$ & 28.7 & 26.4 & 21.5 & 26.3 & 30.1 & 28.2 \\
\hline
\end{tabular}

\subsection{Total Land Equivalent Ratio}

Intercropping ratio of sweet bail to maize crop had a significant $(\mathrm{P}<0.05)$ effect on the total land equivalent ratio in both years and the combined mean. In 2017 cropping year maximum LERt (1.64) was obtained from $75 \%$ of basil intercropping in maize, which was statistically similar with total land equivalent ratio (1.45) obtained from $100 \%$ basil in $100 \%$ maize and $50 \%$ basil intercropping in $100 \%$ maize treatments. The lowest LERt (1.07) was recorded from $25 \%$ basil intercropping in $100 \%$ maize treatment. In 2018 cropping year higher LERt (1.86) was obtained from 100\% basil intercropping in $100 \%$ maize treatments followed by LERt (1.54) which was obtained from $75 \%$ of basil intercropping in $100 \%$ maize which were statistically similar with the LERt obtained from $50 \%$ basil intercropping in $100 \%$ maize treatment. This total land equivalent ratio difference between the years could be due to the favorable environment condition found in cropping year.

All combined mean LERt intercropping ratio of proportion was above the unity (1.00) indicating the advantages of intercropping over sole cropping. The combined mean yield advantage in terms of total LER indices was greatest in the cases of $100 \%$ basil into $100 \%$ maize intercropping (1.66) which might be attributed to more efficient total resource exploitation and greater overall production. This indicated that additional 0.66 ha $(66 \%)$ more area would have been needed to get equal yield to planting maize and basil in pure stands. The intercropping ratio of basil in maize in additive series from $25 \%, 50 \%, 75 \%$ \& $100 \%$ in maize cropping were showed yield increment advantage in $6 \%, 44 \%$, $59 \%$ and $66 \%$ consecutively over the sole cropping. A similar finding was reported by Girma (2015) on Maize- basil intercropping. Also, Higher LERt were reported by Abate and Alemayehu, 2018; Takele and Mohammed, 2014; Hirpa, 2014 on intercropping fenugreek, field pea, haricot bean and sorghum in maize compared to monocropping of maize in Ethiopia.

\subsection{Monetary Advantage Index (MAI)}

MAI also used to evaluate the economic advantages of the intercropping system. Monetary advantage index was significantly $(\mathrm{p}<0.05)$ influenced by the intercropping ratio of basil in maize in both years and the combined mean. In 2017 cropping year intercropping ratio of $100 \%$ basil into $100 \%$, maize gave significantly higher economic return $\left(22659\right.$ birr ha $\left.^{-1}\right)$; which were statistically similar with MAI obtained from $75 \%$ basil intercropping in $100 \%$ maize and $50 \%$ basil intercropping. The lowest economic return ( 2332 birr ha $^{-1}$ ) was obtained from the intercropping ratio of $25 \%$ basil in $100 \%$ maize this could be due to the low number of basil population that might result in less biomass production in terms of basil yield that affect the economic return.

Table6. Land equivalent ratio and monetary advantage of Intercropping Maize and Basil Crops as Affected by additive \% Proportion for two consecutive years

\begin{tabular}{|c|c|c|c|c|c|c|}
\hline \multirow{2}{*}{ Treatments } & \multicolumn{3}{|c|}{ The total land equivalent ratio } & \multicolumn{3}{c|}{ Monetary advantage index $\left(\right.$ birr ha $\left.^{-1}\right)$} \\
\cline { 2 - 7 } & $2016 / 17$ & $2017 / 18$ & Combined mean & $2016 / 17$ & $2017 / 18$ & Combined mean \\
\hline $100 \%$ Maize+100\%Basil & $1.45 \mathrm{a}$ & $1.86 \mathrm{a}$ & $1.66 \mathrm{a}$ & $22659 \mathrm{a}$ & $31631 \mathrm{a}$ & $27145 \mathrm{a}$ \\
\hline $100 \%$ Maize+75\%Basil & $1.64 \mathrm{a}$ & $1.54 \mathrm{ab}$ & $1.59 \mathrm{a}$ & $16194 \mathrm{a}$ & $22961 \mathrm{ab}$ & $19577.5 \mathrm{~b}$ \\
\hline $100 \%$ Maize+50\%Basil & $1.44 \mathrm{a}$ & $1.43 \mathrm{~b}$ & $1.44 \mathrm{~b}$ & $15623 \mathrm{a}$ & $15191 \mathrm{~b}$ & $15407 \mathrm{~b}$ \\
\hline $100 \%$ Maize+25\%Basil & $1.07 \mathrm{~b}$ & $1.06 \mathrm{c}$ & $1.06 \mathrm{c}$ & $2332 \mathrm{~b}$ & $1484 \mathrm{c}$ & $1908 \mathrm{c}$ \\
\hline LSD $_{0.05}$ & $0.28^{*}$ & $0.22^{*}$ & $0.17^{*}$ & $10535^{*}$ & $9174.6^{*}$ & $6439.3^{*}$ \\
\hline CV\% & 10.24 & 7.4 & 5.7 & 28.9 & 32.3 & 31.2 \\
\hline
\end{tabular}


In second year maximum economic return (31631birr ha ${ }^{-1}$ ) was obtained from the $100 \%$ basil intercropping ratio in $100 \%$ maize and the lowest economic return (1484birr ha ${ }^{-1}$ ) from $25 \%$ basil intercropping in maize. Similarly the combined mean economic return was recorded from $100 \%$ basil intercropping in $100 \%$ maize and the lowest economic return obtained from $25 \%$ basil intercropping in $100 \%$ maize. These results suggest that intercropping ratio could improve the smallholder farmers' incomes and total efficiency of the system with low input investment by varying planting population and time. Similar finding was reported by Girma (2015) on Maize- basil intercropping.

\section{CONCLuSion}

The trial conducted for two years when we concluded; mean grain yield of maize was not significantly affected by treatment of intercropping ratio of basil, whereas mean herbage yield of basil was significantly affected by the intercropping ratio of basil proportion in maize. Intercropping basil population in $100 \%$ and $75 \%$ in to $100 \%$ maize gave higher mean grain yield of maize, basil herbage and economically profitable as compared to sole maize and sole basil cropping therefore we recommend intercropping $75 \%$, up to $100 \%$ sweet basil population in maize is would be profitable for small scale farmers who practice monocropping around wondo genet and similar agro-ecology.

\section{ACKNOWLEDGMENT}

We would like to acknowledge Crop Research Directorate and wondo Genet Agricultural Research Center for providing all the necessary facilities and support during the entire experimentation. Our sincere appreciation goes to Gizachewu Atinafu, Cherenet Tefera, Birara Tilahun, Zerihun Jonba, Berso me'eso, and Alemitu Teka for providing all the necessary facilities and support during the field and laboratory works.

\section{REFERENCES}

[1] Ghosh P.K., Mohanty M., Bandyopadhyay K.K., Painuli D.K., Misra A.K., Growth, competition, yield advantage, and economics in soybean/pigeon pea intercropping system in semi-arid tropics of India, I. Effect of subsoiling. Field Crop Research 96: 80-89, (2006).

[2] Chen Y.-q., Luan C., Shi X.-p., Xanthium suppression under the maize-sunflower intercropping system. Journal of Integrative Agriculture 11(6): 1026-1037,(2012).

[3] Lithourgidis A.S., Vlachostergios D.N., Dordas C.A., Damalas C.A., Dry matter yield, nitrogen content, and competition in pea-cereal intercropping systems. European Journal of Agronomy, 34: 287-294,(2011).

[4] Seran T. H. and Brintha I., Review on maize-based intercropping. Journal of Agronomy, vol. 9, no. 3, pp. 135-145, (2010).

[5] Ghanbari A., Dahmardeh M., Siahsar B. A., and Ramroudi M., Effect of maize (Zea mays L.) cowpea (Vigna unguiculataL.) intercropping on light distribution, soil temperature and soil moisture in an environment," J. Food Agr Environ, vol. 8, pp.102-108 (2010).

[6] Sujatha S., Bhat R., Kannan C., Balasimha D., Impact of intercropping of medicinal and aromatic plants with organic farming approach on resource use efficiency in areca nut (Areca catechu L.) plantation in India. Industrial Crops and Products 33: 78-83 (2011).

[7] Muoneke C.O., Mbah E.U. Productivity of cassava/okra intercropping systems as influenced by okra planting density. African Journal of Agricultural Research 2(5): 223-231(2007).

[8] Uddin R.O., Odebiyi J.A., Influence of intercropping on incidence, abundance and severity of pest damage on okra (Abelmoschus esculentus (Linn.) Moench) (Malvaceae) and chili pepper (Capsicum frutescence Linn.) Journal of Agricultural Science 3(3): 63-66, (2011).

[9] Maffei M., Mucciarelli M., Essential oil yield in peppermint/soybean strip intercropping. Field Crop Research 84: 229-240, (2003).

[10] Poggio S.L., Structure of weed communities occurring in monoculture and intercropping of field pea and barley. Agriculture, Ecosystems and Environment 109: 48-58, (2005).

[11] Echarte L., Della Maggiora A., Cerrudo D., Gonzalez V.H., Abbate P., et al., Yield response to plant density of maize and sunflower intercropped with soybean. Field Crop Research 121: 423-429,( 2011).

[12] Esmaeili A., Sadeghpour A., Hosseini S.M.B., Jahanzad E., Chaichi M.R., Hashemi M., Evaluation of seed yield and competition indices for intercropped barley (Hordeum vulgare) and annual medic (Medicago scutellata). International Journal of Plant Production 5(4): 395-404, (2011).

[13] Banik P., Midya A., Sarkar B.K., Ghose S.S., Wheat and chickpea intercropping systems in an additive series experiment: Advantages and weed smothering. European Journal of Agronomy 24: 325-332, (2006). 
[14] Helen, D., The cultivated basils. Buckeye Printing, Independence, Mo (1980).

[15] Gebrehiwot H., Bachetti, R., \& Dekebo, A., Chemical composition and antimicrobial activities of leaves of sweet basil (Ocimum basilicum L.) herb. Int J Basic Clin Pharmacol. 4(5):869-875,(2015).

[16] Simon, J.E., Morales M.R., Phippen W.B., Vieira R.F., and Hao Z. Basil, A source of aroma compounds and a popular culinary and ornamental herb. In: J. Janick (ed.), Perspectives on new crops and new uses. ASHS Press, Alexandria, VA p. 499-505 (1999).

[17] Yimer, M., Home Gardens of Ethiopia (2010).

[18] Lulie B., Getu H. and Bogale T., Intercropping of Maize (Zea mays L.) with Spearmint (Mentha spicata L.) as Supplementary Income Generation at Wondo Genet Agricultural Research Center, South Ethiopia. International Journal of Recent Research in Life Sciences. Vol. 1 pp: 31-43. (2014).

[19] Willey, R.W., Evaluation and presentation of intercropping advantages. Exp. gric.21:119-(1991).

[20] Willey, R.W., Intercropping-its importance yield advantages. Agron. J. 71(2): 115-119, (1979).

[21] Ghanizadeha H., bicharanlou B., zaefarian F., Bagheri M., Study of intercropping of maize with sweet basil and borage. Cercetări Agronomice in Moldova Vol. XLVII, No. 2 (158) (2014). DOI: 10.2478/cerce-20140013

[22] Girma A., Yield Advantage and Economic Benefit of Maize Basil Intercropping under Different Spatial Arrangements and Nitrogen Rates. Scholarly Journal of Agricultural Science Vol. 5(8), pp. 296-302 (2015).

[23] Abate M. and Alemayehu. G., Biological Benefits of Intercropping Maize (Zea mays L) with Fenugreek, Field Pea and Haricot Bean Under Irrigation in Fogera Plain, South Gonder Zone, Ethiopia. Agriculture, Forestry, and Fisheries. Vol. 7, No. 1, pp. 19-35, (2018). doi: 10.11648/j.aff.20180701.14

[24] Takele A. and Mohammed J, Time of Haricot Bean Intercropping into the Maize-Based Cropping Systems under Conservation Tillage in the Rift Valley of Ethiopia. Ethiop. J. Agric. Sci. 26(2) 11-26 (2016).

[25] Hirpa T., Effect of intercrop row arrangement on maize and haricot bean productivity and the residual soil. World Journal of Agricultural Sciences, 2 (4): 069- 077, (2014).

Citation: Nebret Tadesse, et.al, "Intercropping of Sweet Basil (Ocimum Basilicum L.) with Maize (Zea Mays L.) as Supplementary Income Generation at Wondo Genet Agricultural Research Center, South Ethiopia” International Journal of Research Studies in Agricultural Sciences (IJRSAS), 2019; 5(9), pp. 37-43, http://dx.doi.org/10.20431/2454-6224.0509005

Copyright: () 2019 Authors. This is an open-access article distributed under the terms of the Creative Commons Attribution License, which permits unrestricted use, distribution, and reproduction in any medium, provided the original author and source are credited. 